\title{
RECENT DIAGNOSTIC OPPORTUNITIES IN ULTRASOUND DIAGNOSTICS OF LOWER EXTREMITIES DEEP VEINS THROMBOSIS
}

\author{
Zubarev A.R., Krivosheeva N.V., Rychkova I.V., Demidova A.K., Nikolskiy S.E.
}

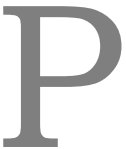

urpose. The aim of this study was to analyze physical basis and assess opportunities and advantages of new ultrasound technologies: quantitative assessment of acoustic structures (Acoustic Structure Quantification, ASQ), ultrasound elastography (USE), mapping of microvascular bedflow with high spatial and temporal resolution (Superb Microvascular Imaging, SMI) in evaluation of patients with venous thrombosis of lower extremities.

Materials and methods. The study involved 72 patients $(41$ men $-56,9 \%$ and 31 women $-43,1 \%$ ) aged $42-85$ with venous thrombosis of lower extremities (144 lower extremities). All patients had undergone standard ultrasound investigation including B-mode, color duplex or power doppler imaging modes. In addition to standard modes we used new ultrasound technologies announced by Toshiba Medical Systems and listed among options in ultrasound system Aplio ${ }^{\mathrm{TM}} 500$.

Results. We assessed condition of main veins of lower extremities, including revealing of thrombotic changes and estimation of the spreading level and composition of thrombotic masses. During dynamic follow-up signs of the initial stages of recanalization were revealed and comparison of thrombolysis process intensity with further follow-up studies was performed. A significant advantage of new technologies in comparison with a standard ultrasound examination was established.

Conclusions. Acoustic Structures Quantification, ultrasound elastography and Superb Microvascular Imaging of Toshiba Medical Systems can be effectively used for examining patients with venous thrombosis in the system of inferior vena cava. Taking into consideration the fact that these technologies are highly informative, not time consuming and simple in everyday use they can be recommended to be included into standard ultrasound investigation for precise assessment of revealed abnormalities.

Keywords: ASQ, ultrasound elastography, SMI, AplioAplio ${ }^{\mathrm{TM}} 500$ of Toshiba Medical Systems, venous blood flow, microvascular bed, thrombotic masses, venous thrombosis, recanalization processes.

Corresponding author: Zubarev A.R., a.zubarev@mail.ru

For citation: Zubarev A.R., Krivosheeva N.V., Rychkova I.V., Demidova A.K., Nikolskiy S.E. Recent diagnostic opportunities in ultrasound diagnostics of lower extremities deep veins thrombosis. REJR. 2016; 6 (2):44-53. DOI:10.21569/2222-7415-2016-6-2-4453.

Received: 17.02.2016

Accepted: 29.02.2016

\section{НОВЫЕ АИАГНОСТИЧЕСКИЕ ВОЗМОЖНОСТИ В УАЬТРАЗВУКОВОЙ АИАГНОСТИКЕ ТРОМБОЗОВ ВЕН НИЖНИХ КОНЕЧНОСТЕЙ}

\author{
Зубарев А.Р., Кривошеева Н.В., Рычкова И.В., \\ АемиАОва А.К., НИкольСКИЙ С.Е.
}

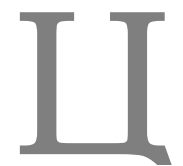

емь исследования. Проанализировать физические основы и оценить возможности и преимущества новых техномогий - количественной оценки акустической структуры (Acoustic Structure Quantification ASQ), ультразвуковой эмастографии (УЗЭГ), картирования микрососудистого русла с высоким пространственно-временным разрешением SMI (Superb Microvascular Imaging) в обследовании пациентов с венозными тромбозами нижних конечностей.

Материамы и методы. В исследование вкАючено 72 пациента (144 конечно-

ГБОУ ВПО «Российский национамьный исследовательский университет им. Н.И. Пирогова" Минздрава России. г. Москва, Россия. 


\section{RUSSIAN ELECTRONIC JOURNAL OF RADIOLOGY}

сти), поступивших в стационар с венозными тромбозами вен нижних конечностей в возрасте от 42 до 88 мет. Мужчин было 41 (56,9\%), женщин 31 (43,1\%). Всем включенным в исследование пациентам проводимось стандартное ультразвуковое обследование с использованием В-режима и режима цветного дуплексного или энергетического сканирования. Затем были применены новые методики, анонсируемые компанией Toshiba, используемые в ультразвуковом приборе Aplio ${ }^{\mathrm{TM}} 500$.

Резумьтаты. Была проведена оценка состояния магистрацьных вен нижних конечностей, включающая выявления тромботических изменений и определение уровня распространения и характера тромботических масс. При проведении динамического наблюдения определялись признаки начальных процессов реканализации и сопоставлялась активность протекающих процессов мизиса тромба при последующих исследованиях. Выявлены преимущества используемых методик при сравнении со стандартным ультразвуковым исследованием.

Выводы. Методики ASQ, УЗЭГ, SMI ультразвукового прибора Aplioтм 500 компании Toshiba могут с успехом применяться для обследования пациентов с венозными тромбозами в системе нижней полой вены, а учитывая их информативность, небольшую время затратность и простоту использования, могут быть рекомендованы дмя вкАючения в объем стандартного ультразвукового обследования дмя детализации выявценных изменений.

КАючевые слова: ASQ, УЗЭГ, SMI, Aplioтм 500 компании Toshiba, венозный кровоток, микрососудистое русло, тромботические массы, венозный тромбоз, процессы реканализации.

Контактный автор: Зубарев A.P., a.zubarev@mail.ru

Дия цитирования: Зубарев А.Р., Кривошеева Н.В., Рычкова И.В., Демидова А.К., Никольский С.Е. Новые диагностические возможности в ультразвуковой диагностике тромбозов вен нижних конечностей. REJR. 2016; 6 (2):44-53. DOI:10.21569/22227415-2016-6-2-44-53.

Статья получена: 17.02.2016

Статья принята: 29.02.2016

raditionally all diagnostically important programs for investigation of patients with venous thrombosis in the system of inferior vena cava were based on color duplex scanning only. In the last decade new technologies based on fundamental principles of essential optics, considering peculiarities of visual perception were becoming more and more popular.

Nowadays it is obvious that particularly because of physiological peculiarities of visual perception, based on such fundamental principles as binocular vision (our ability to see with two eyes), accommodation (adaptation of eyes in order to see the object precisely on different distances) and convergence (simultaneous inward movement of eyes toward each other) further progress of visualizing ultrasound technologies is becoming evident. No doubt that helps to significantly increase diagnostic value of date acquired during standard ultrasound examination.

\section{Puprose.}

The aim of this study was to analyze physical basis and assess opportunities and advantages of new ultrasound technologies: quantitative assessment of acoustic structures (Acoustic Structure Quantification, ASQ), ultrasound elastography (USE), mapping of microvascular bedflow with high spatial and temporal resolution (Superb
Microvascular Imaging, SMI) in evaluation of patients with venous thrombosis of lower extremities.

\section{Materials and methods.}

The study involved 72 patients (41 men $56,9 \%$ and 31 women $-43,1 \%$ ) aged $42-85$ with venous thrombosis of lower extremities (144 lower extremities).

All patients had undergone standard ultrasound investigation including B-mode, color duplex or power doppler imaging modes. In addition to standard modes we used new ultrasound technologies announced by Toshiba Medical Systems and listed among options in ultrasound system Aplio $^{\text {TM }} 500$.

Ultrasound investigation included following assessment steps:

1.Evaluation of lower extremities venous system condition in B-mode, estimation of the spreading level and composition of thrombotic masses in the lumen.

2.Investigation of thrombotic masses structure in ASQ mode.

3.Evaluation of tissue elastic properties in USE-mode.

4.Comparison of results in B-mode with data in ASQ and USE.

5.Evaluation of bloodflow in the lumen of 


\section{RUSSIAN ELECTRONIC JOURNAL OF RADIOLOGY}

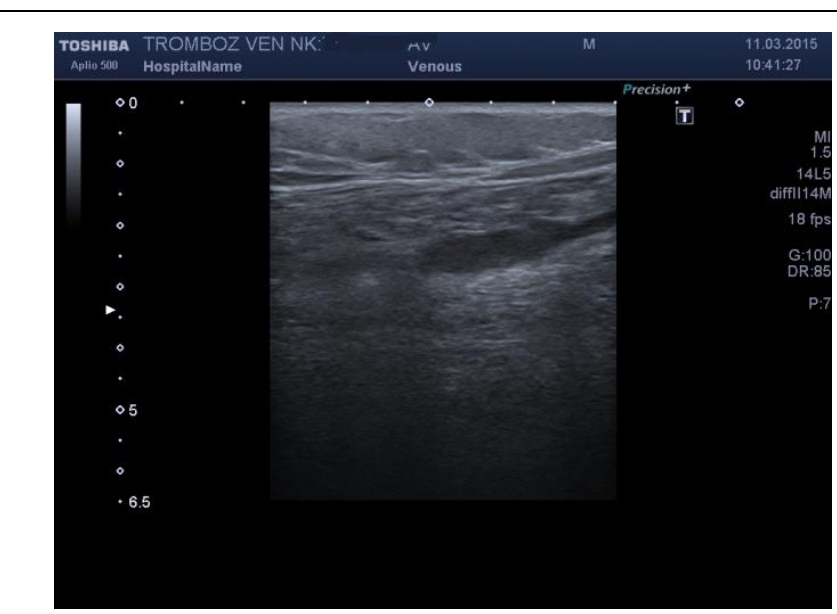

Рис. 1, a.

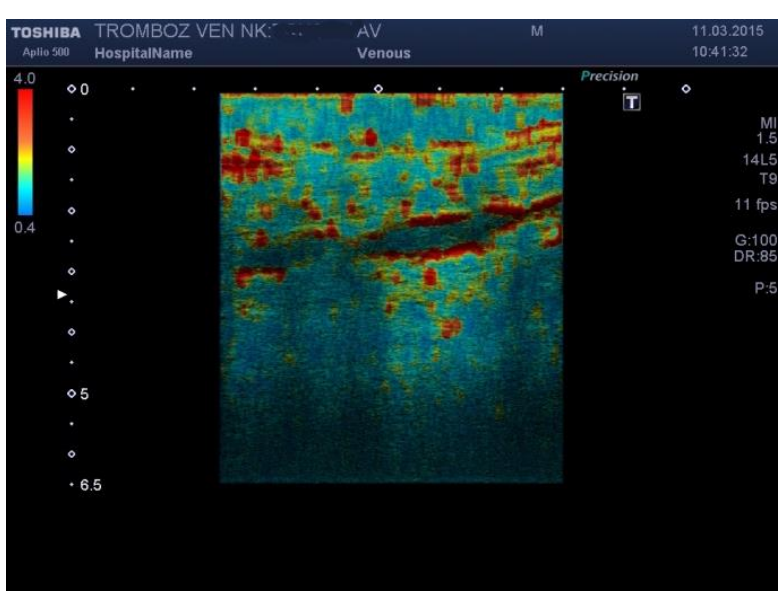

Рис. 1, b.

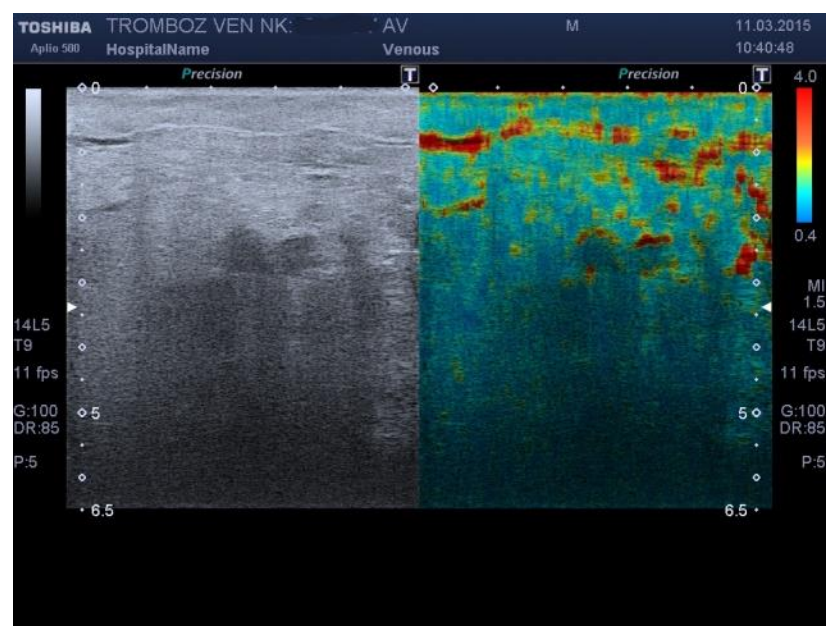

Pис. 1, с.

\section{Рис. 1. Sonograms.}

A - B-mode.

B - ASQ mode, these masses are color coded as homogeinic.

C - B-mode and ASQ mode, cross-sectional view of the lumen of vein with hypoechoic masses.

thrombotized vein by color duplex scanning or power doppler mode.

6.Estimation of bloodflow in the lumen of thrombotized deep vein along the whole length by SMI, assessing: a) presence of non-vascular foci, b) uniformity and intensity of vascular component, c) evaluation of the level of thrombotic masses spreading.

7.Comparison of SMI - mode investigation results with color doppler imaging (CDI).

\section{Results.}

Toshiba ultrasound scanners are equipped with unique, time saving technologies which help to increase diagnostic value of ultrasound examination of the patient significantly. One of the most important features of these technologies is that no complex diagnostic approaches needed to be used. The same time we can get additional and very valuable clinical information. Which new technolo- gies offered to us as professionals in ultrasound? Acoustic Structure Quantification (ASQ).

This technology is based on mathematical principle of all signals amplitudes processing resulted in assessment of evaluated tissue heterogeneity.

ASQ helps to see all investigated tissues in details being based on fundamental principles of essential optics we discussed above. Color mapping of tissue heterogeneity as method is an effective tool for revealing hypoechoic structures in vessel lumen which cannot be recognized thoroughly in B-mode [1]. On the pictures below we can see examples of comparison of B-mode with ASQ. Pictures 1 (a, b, c) demonstrates B-mode and the lumen of vein with hypoechoic masses, in ASQ mode these masses are color coded as homogeinic.

Pictures 2 (a, b) also shows us hypoechoic 


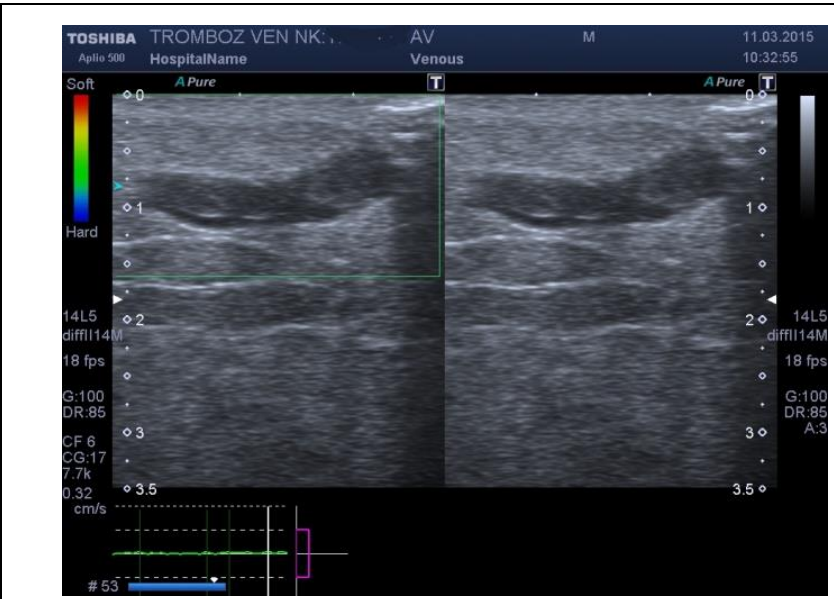

Рис. 2, a.

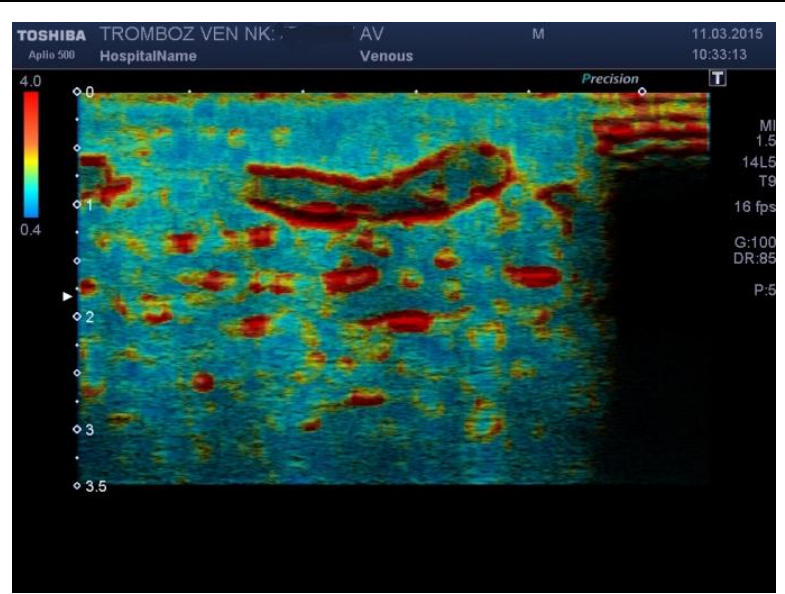

Рис. 2, b.

Pис. 2. Sonograms.

A - B-mode, hypoechoic masses in the lumen of vein.

B - ASQ mode, these masses are color coded as heterogeneous, with components along its contour as well as in the center of thrombotic masses.

masses in the lumen of vein, but in ASQ these masses are color coded as heterogeneous, with components along its contour as well as in the center of thrombotic masses.

On the following pictures we can easily see heterogeneous thrombotic masses with prevalence of hypoechoic component in the lumen of cubital vein in ASQ (pic. 3 (a, b)). Heterogeneity of thrombotic masses can be observed better in fragments of the vein where lumen is almost anechogeneic in B-mode.

The same kind of changes in thrombotic masses structure in the patient with occlusive thromposis of femoral vein can be observed on pictures 4 (a, b).

Thus being a very easy to use the method

Рис. 3, a.

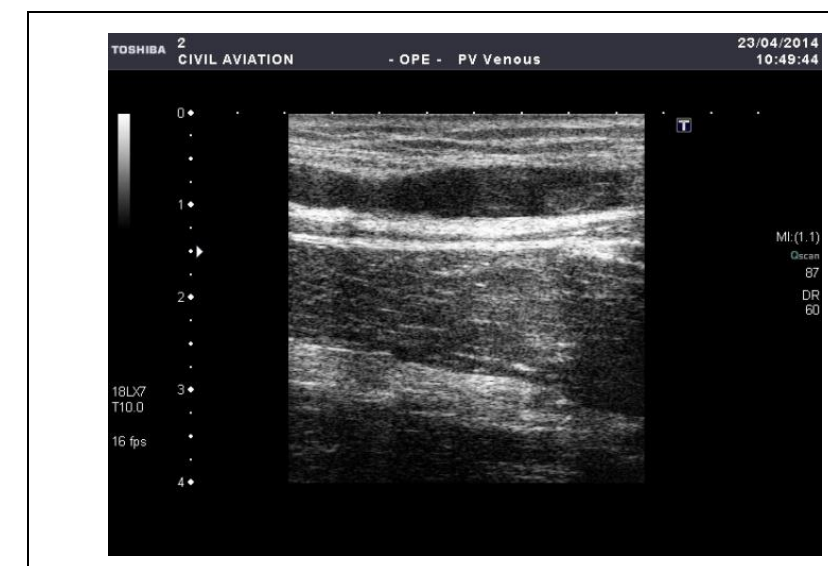

ASQ helps to improve visual perception by a human eye and let the examiner differentiate evaluated data faster and more effectively. Moreover it helps to understand structural heterogeneity of studied tissue in a very short period of time.

Ultrasound Elastography. (Color mapping of elasticity characteristics of tissues).

Elasticity of biological tissue is a property of reversible deformation based on capability of tissue to offer mechanical resistance towards influencing external force and to return to its initial shape after force is removed. Tissue elastic properties depend on its structural organization. It is obvious that Ultrasound Elastography (USE) as any imaging method has its pros and cons. Advantages:

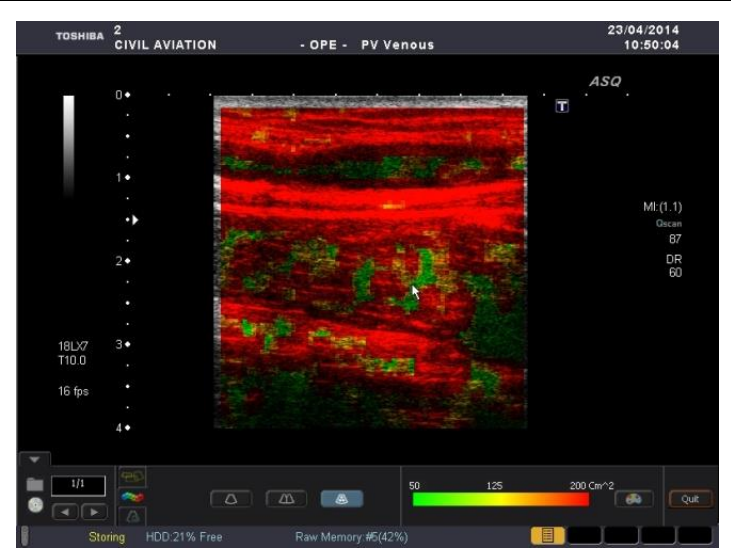

Рис. 3, b.

Pис. 3. Sonograms.

A - B-mode, there are heterogeneity of thrombotic masses with prevalence of hypoechoic component in the lumen of cubital vein.

B - ASQ mode, heterogeneity of thrombotic masses can be observed better in fragments of the vein where lumen is almost anechogenic in B-mode. 
- An opportunity to detect elastic properties of tissues in addition to data about tissue echostructure

- Non-invasive tool

- Professional recertification for professionals in ultrasound diagnostic area is not required

Among the most remarkable drawbacks of this technology we would mention absence of thoroughly worked out recommendations for us- provide us with additional information. In nonocclusive type of thrombotic masses bloodflow in intact venous segments cannot be revealed. It is completely different in case of USE implementation: intact segment of vein with blood flow is color mapped with a red color when thrombotic masses in the lumen of vein are colored with blue as more denser structure (pic. 5 (a-f)).

Thus due to the high sensitivity in differen-

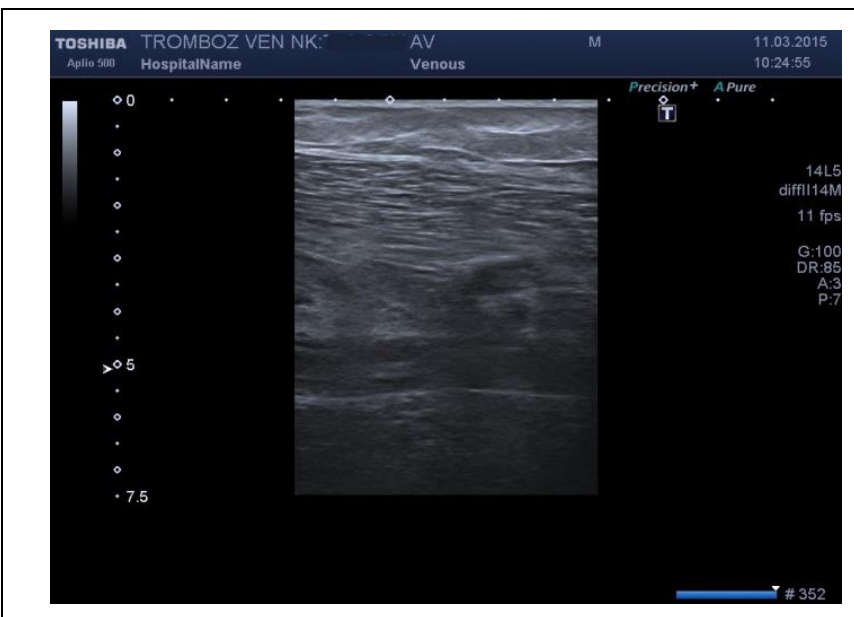

Рис. 4, a.

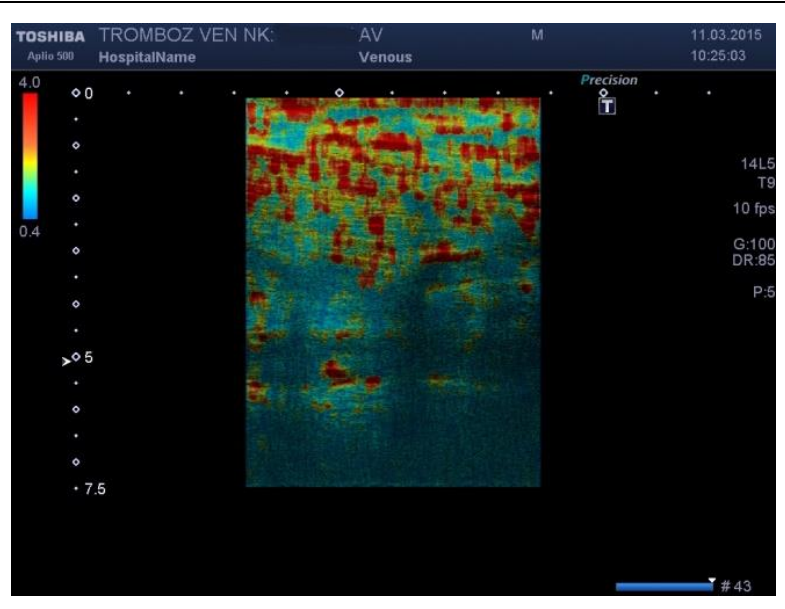

Рис. 4, b.

\section{Рис. 4. Sonograms.}

A, B - The same kind of changes in thrombotic masses structure in the patient with occlusive thromposis of femoral vein can be observed in B-mode (a) and in ASQ mode (b).

age of this technology.

Types of ultrasound elastography.

Static (compressive) elastography:

- Deformation of tissue is initiated by the hand of an examiner

- Comparison of elasticity in different focuses of investigated tissue

Dynamic elastography

- Deformation of tissue is initiated by shear wave technology

- Estimation of tissue elasticity absolute values

Compressive elastography principle

- A light compression on tissue should be induced (lighter then compression probes) or physiological motion of the organ (pulsation) is used

- Color mapped visualisation of tissue motion degree is performed after mathematical processing of images depending on its elasticity

- Soft tissue are deformed more than hard structures

Implementation of compressive USE in phlebology is limited today. This technology cannot be used in patients with acute venous thrombosis due to the fact that manual compression is required. There is no such a drawback when using dynamic USE. Thus application of dynamic mode of USE hasn't got this limitation and can tiation of elasticity of evaluated tissues we are capable to acquire additional information even in cases with remarkably low visualization in Bmode or when studying very narrow blood vessel.

Advanced Dynamic Flow (ADF).

This technology is exclusive patented imaging method of Toshiba Medical Systems that is used for visualization of main and parenchymal bloodflow and based on both high spatial and temporal resolution as well as high frame rate. Using Advanced Dynamic Flow as a tool we can analyze jets even in very narrow vessels at a very low level of speed scale with simultaneous detection of jet direction. ADF combines high frequency range which used for composition of images in Bmode mostly with specific algorithm of doppler signal processing when static signal reflected from tissues is filtered. In addition to that we can evaluate not only superficial but deep main vessels and study parenchymous bloodflow also. It is crucially important that there is no "filling-up" effect at the intima borderline. Thus on echograms shown below we can see the difference between two modes: CDI and ADF (pic. 6 (a, b)). In case with ADF, the lumen of partially thrombotized vein (intact segment) is visualized remarkably well.

Mapping of microvascular bedflow with high 


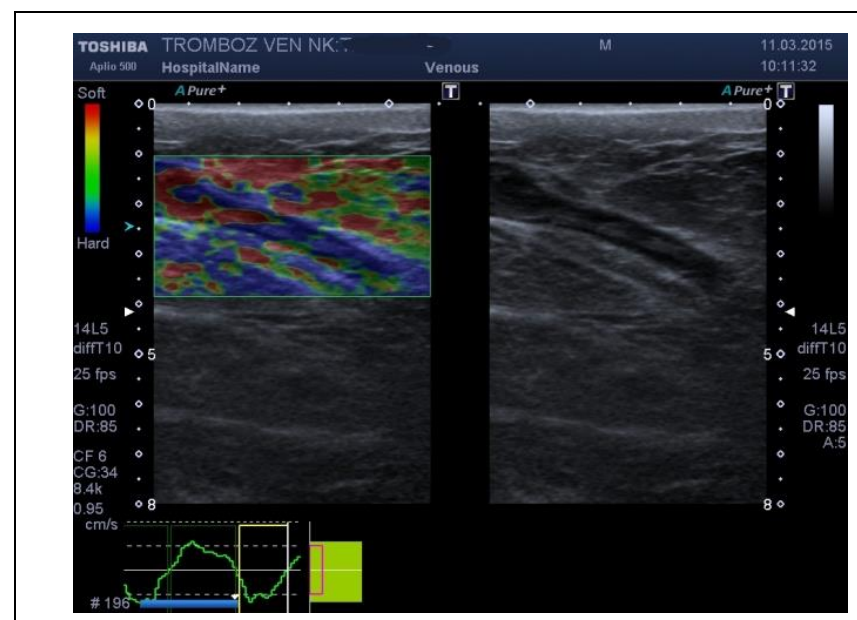

Рис. 5, a.

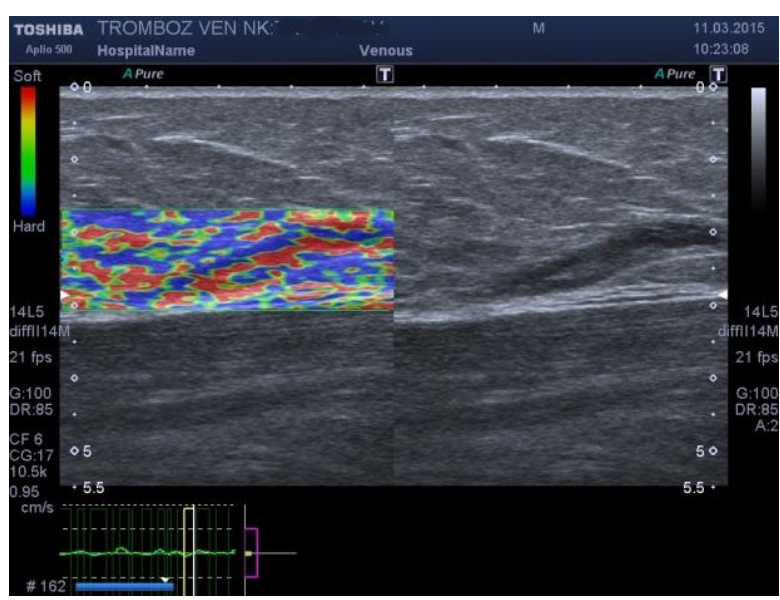

Рис. 5, с.

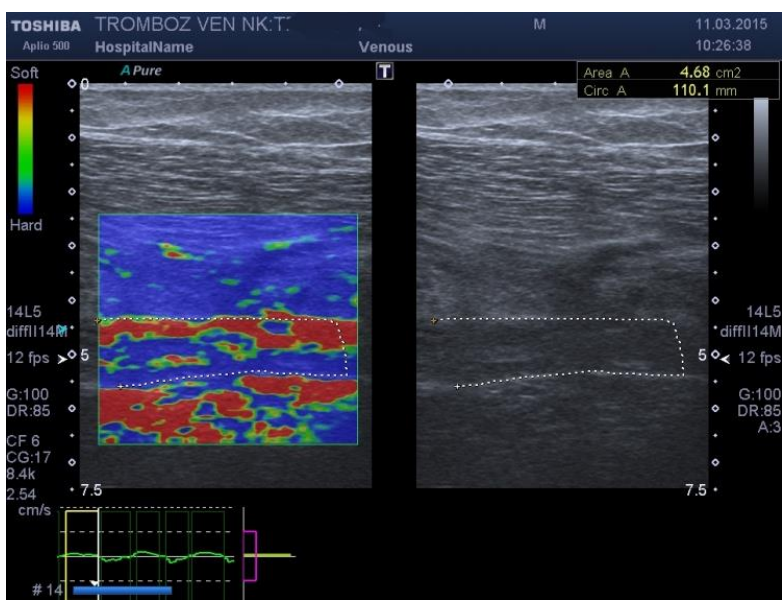

Рис. 5, е.

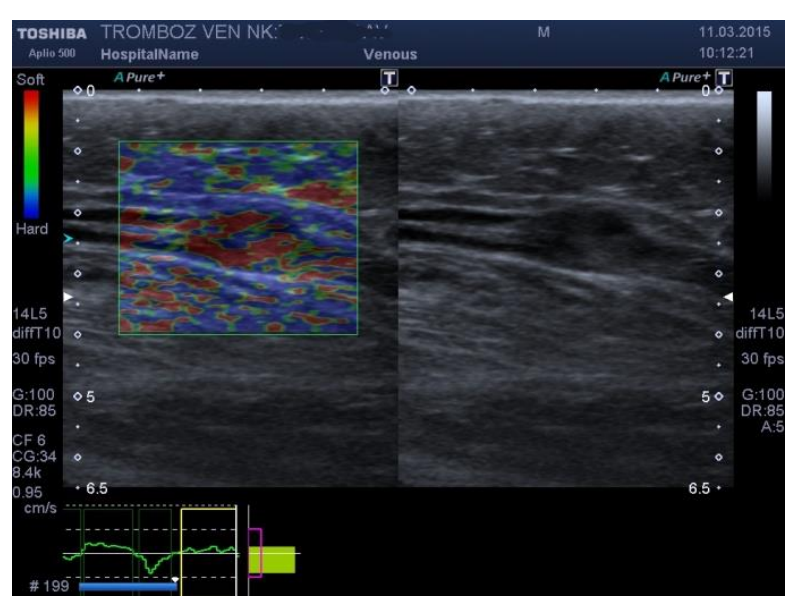

Pис. 5, b.

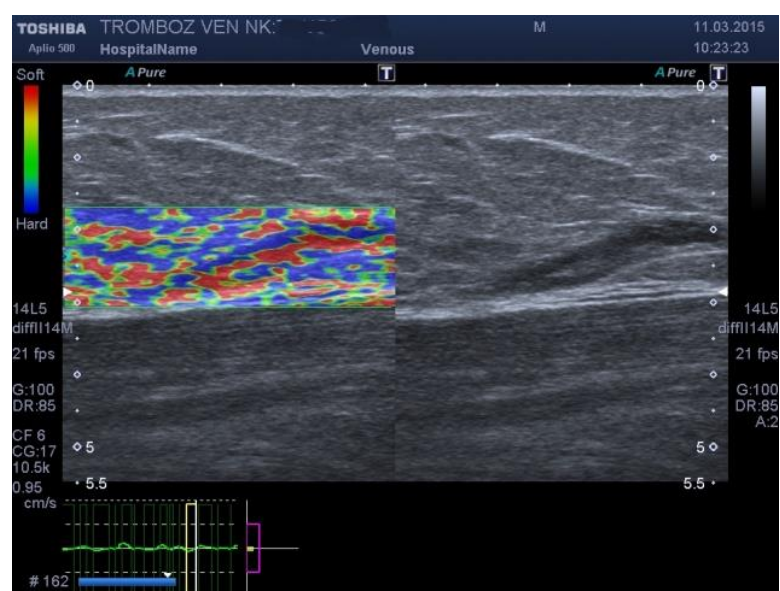

Puc. 5, d.

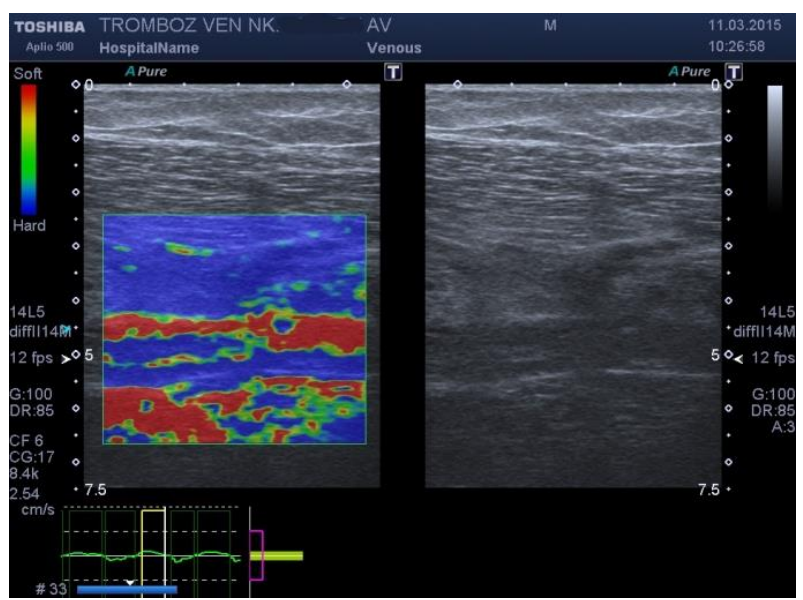

Рис. 5, f.

\section{Pис. 5 (a-f). Sonograms.}

In non-occlusive type of thrombotic masses blood flow in intact venous segments cannot be revealed. It is completely different in case of USE implementation: intact segment of vein with blood flow is color mapped with a red color when thrombotic masses in the lumen of vein are colored with blue as more denser structure. 


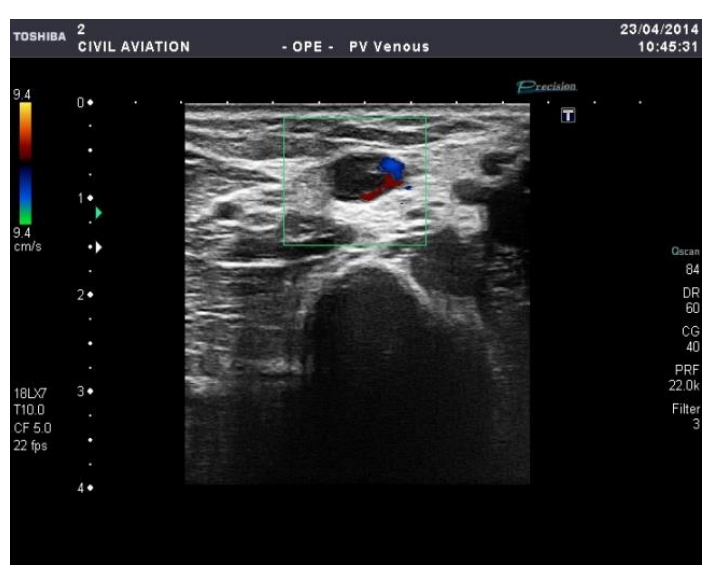

Рис. 6, a.

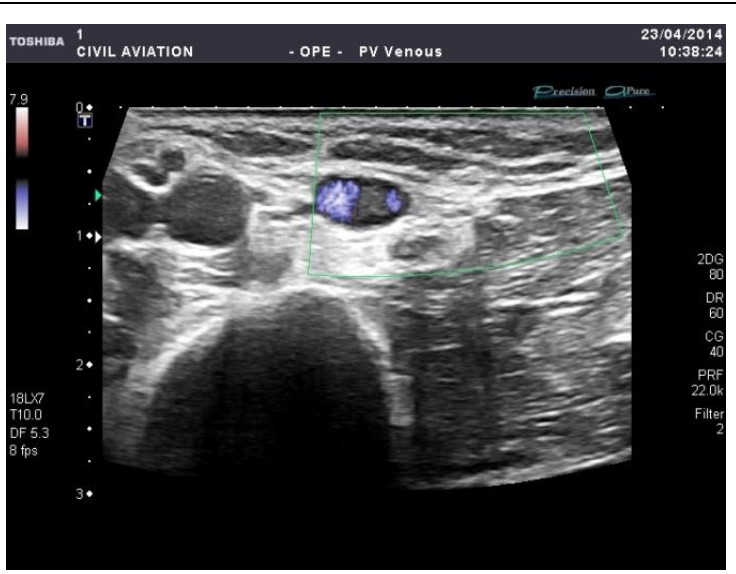

Рис. 6, b.

Рис. 6. Sonograms.

A - CDI-mode, B - ADF-mode. In case with ADF, the lumen of partially thrombotized vein (intact segment) is visualized remarkably well.

spatial and temporal resolution

Superb Microvascular Imaging (SMI).

Nowadays we can hardly imagine progress in the field of modern ultrasound science without application of color imaging modes based on doppler imaging. We would definitely not be able to overestimate high practical importance of conventional color doppler mapping, power doppler and $\mathrm{ADF}$ recognized as robust and reliable partners of ultrasound professionals in all areas of diagnostic ultrasound. Because of conventional doppler especially it is possible to get valuable information about vascular architectonics of evaluated organ, investigate hemodynamics characteristics of speed scale in the vessel. At the same time, being highly informative and indispensable tool in modern clinical practice, doppler technology due to essential physical limitations cannot provide examiner with comprehensive and precise information when studying low speed jets. All attempts, directed to minimize the presence of motion artifacts by decreasing a speed scale and diminishing color gain in doppler mode cannot help to manage it effectively. Due to that particularly in some studies we have to use contrast agents and perform Contrast Enhanced Ultrasound Study (CEUS). But is that conception true that technology of contrast visualization is the only available practical solution and potential opportunities of doppler technology completely exhausted itself? In case we answer this question as objective as we can it would be obvious that even CEUS has its disadvantages in visualization of microvascular bed. In accordance to research data contrast imaging in evaluation of lymphatic nodes is considered to be less informative when lymphatic nodes are less than $5 \mathrm{~mm}$ (3). Taking into consideration the fact that use of contrast agents increase price of ultrasound examination significantly today we should also mention financial aspect of this technology used in modern ultrasound diagnostics. Due to this reason and because of adverse reaction risk it is obvious that new technology which can provide us high level of diagnostic accuracy equal to contrast imaging methods, but without injection of a contrast substance, is eagerly welcomed by ultrasound audience. At least, this method should be considered as full alternative to existing methods of investigation with the use of contrast agents, particularly in patients with diagnosed adverse reaction induced by contrast agent in anamnesis or in patients with burdened allergic anamnesis. Practical experience of conventional color doppler application which has been accumulated in the field of ultrasound diagnostics for years made it possible to present a new imaging technology based on color doppler imaging. We are totally agree with an opinion that today we can see what couldn't be seen before, be beyond formerly established by conventional doppler imaging limits. Today we have got opportunity of minimal diameter vessels investigation in absence of motion artifacts. That is how we can briefly describe this tremendously important feature of Superb Microvascular Imaging. But where is it the secret of this technology with genuinely unprecedented opportunities for vascular ultrasound diagnostics? Remarkably important fundamental principles of this technology are based on:

1.Opportunity to operate at high frequency (more than 50 frame per second)

2.Establishing of scale values up to 1.3 $\mathrm{cm} / \mathrm{sec}$

Technology of microvascular bed mapping with high spatial and temporal resolution presented by two modes: monochromatic and color. The first has higher sensitivity in comparison with col or mode. In addition to that color palette is availa- 


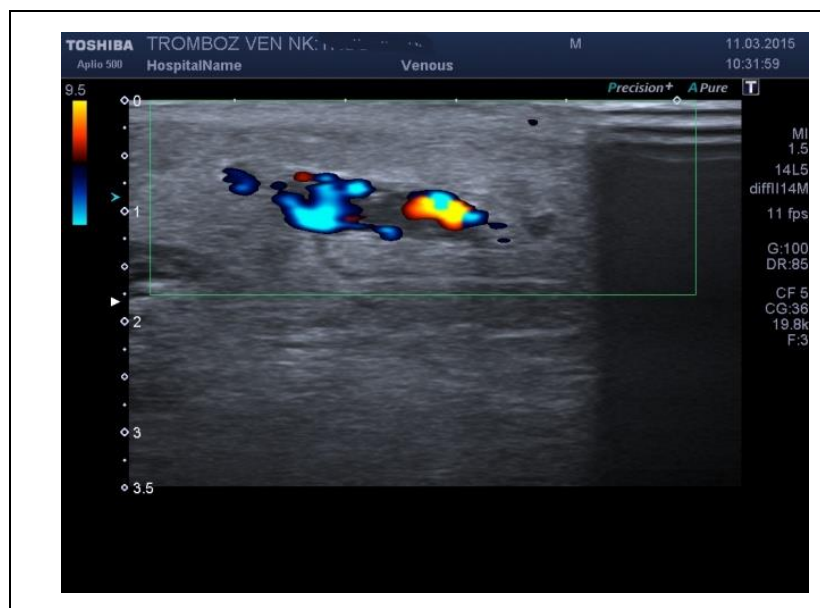

Рис. 7, a.

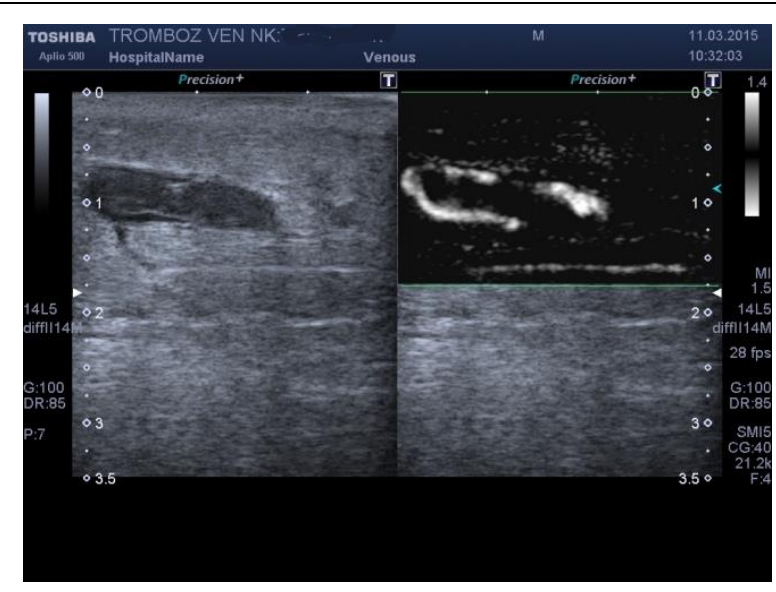

Pис. 7, b.

\section{Puc. 7. Sonograms.}

A - CDI-mode, heterogeneous thrombotic masses in venous lumen and color mapped blood flow at non-thrombotized segment of the vein are visualized.

B - SMI-mode, in comparison with CDI mode in SMI we can evaluate each characteristic simultaneously, which .leads to decreasing the investigation time and significant increase of diagnostic confidence.

ble and any of presented colors can significantly improve quality of visualisation. Precise and detailed visualisation of smallest structural components of vascular architectonics is available in this mode. This tremendously important feature is one of the most outstanding features of this technology and makes possible to study vascular architectonics on the highest level of accuracy. Examiner can choose color mode when needed which is important for being able to assess direction of color flow. The same time we should keep in mind that in this mode due to essential physics principles we would definitely loose image resolution and as a consequence decrease of sensitivity level for registration of bloodflow with critically low speed characteristics. Thanks to highly listed peculiarities of this technology, due high sensitivity and new adaptive algorithm of signal processing we are capable to differentiate signals, reflected by tissues from signals corresponding to motion artefacts precisely. Moreover, it is possible to delineate contours of vascular structures at a highest level of accuracy [2]. Potential opportunities of this technology are currently in the process of investigation and among those we were capable to find that there are researches in the area of the liver neoplasm vascularization, assessment of vascularization in tendinitis and ligamentitis in orthopedics, investigation of breast lesions $[4,5,6]$. All authors are unanimous in their opinion regarding the role of SMI as a progressively new era in ultrasound diagnostics. Although, we did not find any descriptions of this technology application for investigation of main vessels, particularly veins.

We initiated our study with assessment of superficial veins. Thus, comparing data acquired in two imaging modes: CDI and SMI heterogeneous thrombotic masses in venous lumen and color mapped bloodflow at non-thrombotized segment of the vein are visualized (pic.7 (a, b)). Nevertheless evaluating color mapped bloodflow we can see "filling-up" effect. Due to this we cannot estimate thrombotic masses contours precisely. In comparison with CDI mode in SMI we can evaluate each characteristic simultaneously, which leads to decreasing the investigation time and significant increase of diagnostic confidence.

Estimation of sapheno-femoral anastomosis (SFA) was performed in all patients with acute thrombosis. We can see SFA with heterogenic thrombotic masses in the lumen of main branch of the great saphenous vein (GSV) (pic. $8(a, b)$ ). In ADF mode bloodflow is registered in the lumen of epigastric inflow and in the segment localized below level of main branch of GSV and epigastric inflow merging.

In SMI mode in the same area we also observed signs of bloodflow in lumen of veins. In addition to that we detected thrombotic masses with well defined contour in the lumen of common femoral vein (CFV). We can conclude that SMI gives us an opportunity to get reliable diagnostic information in time in acute phase as well as during dynamic follow-up for assessment of administered thrombolitic therapy efficacy. Thus, 10 days after development of acute thrombosis, in the lumen of GSV, SFA and common femoral vein (CFV) using SMI we confirmed ultrasound pattern of the initial recanalization as registered bloodflow adja- 


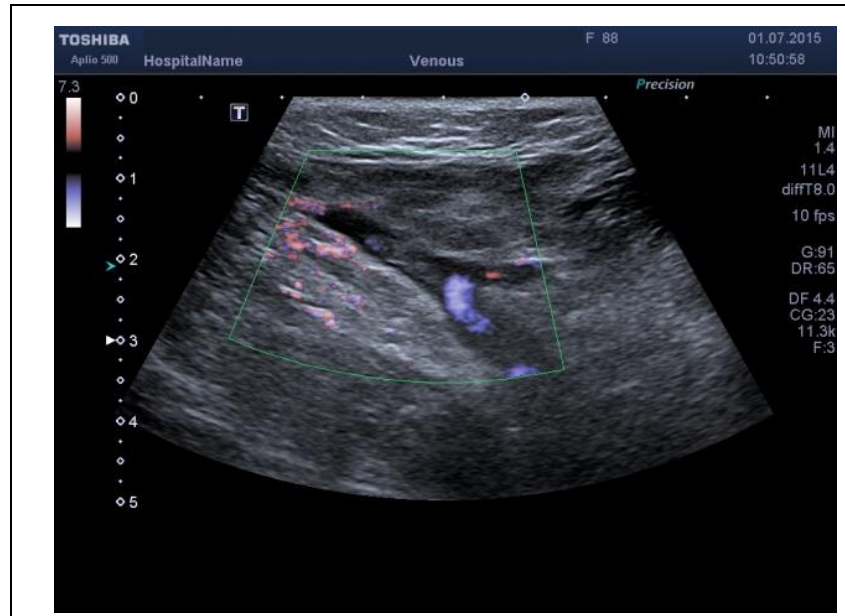

Рис. 8, а.

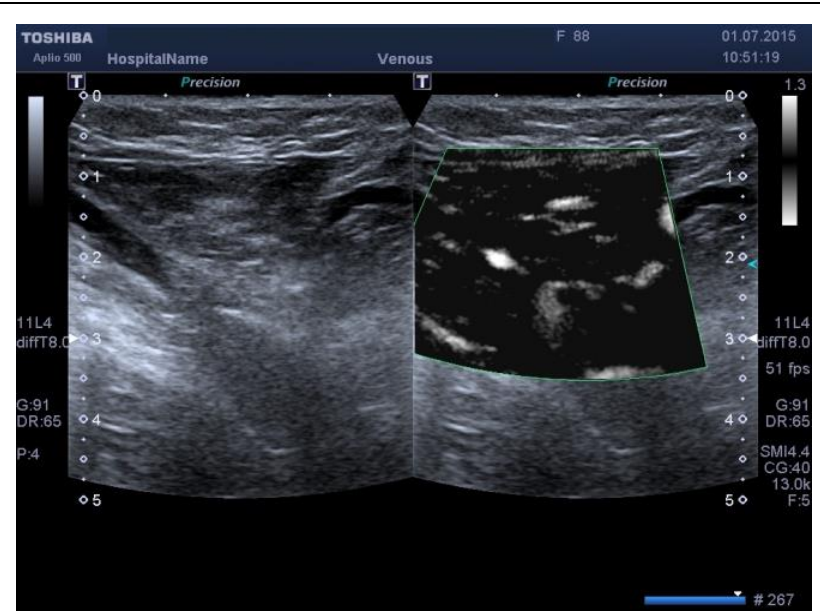

Рис. 8, b.

\section{Рис. 8. Sonograms.}

A - We can see SFA with heterogenic thrombotic masses in the lumen of main branch of the great saphenous vein (GSV).

$\mathrm{B}$ - In ADF mode blood flow is registered in the lumen of epigastric inflow and in the segment localized below level of main branch of GSV and epigastric inflow merging.

cent to the wall. Intensity of coded signal and relevant uniformity of bloodflow besides short time interval from development of thrombotic changes let us made assumption about activation of thrombolysis. This information allows predicting the outcome of thrombotic process since it significantly depends on the degree of retraction of blood clot formation and subsequent thrombolysis.

Our point of view was confirmed by further observation. After one week term visualization of SFA lumen and CFV in B-mode didn't changed significantly. In accordance with data of investigation in SMI mode we confirmed increase of an area and intensity of a bloodflow, typical patterns of active processes of blood clot retraction. Thus, prognosis of thrombotic process is relatively positive and administered thrombolytic therapy is correct (pic. 9 (a, b)).

\section{Discussion.}

Analyzing all of the mentioned above we can conclude that use of SMI in patients with acute venous thrombosis provide more accurate diagnostic information about level of thrombotic masses spreading. During dynamic follow-up this technology helps to assess activity of recanalization process in thrombotic masses.

Implementation of modern technologies in everyday practice is crucially important. It broadens opportunities of ultrasound examination significantly and provides more accurate diagnostic

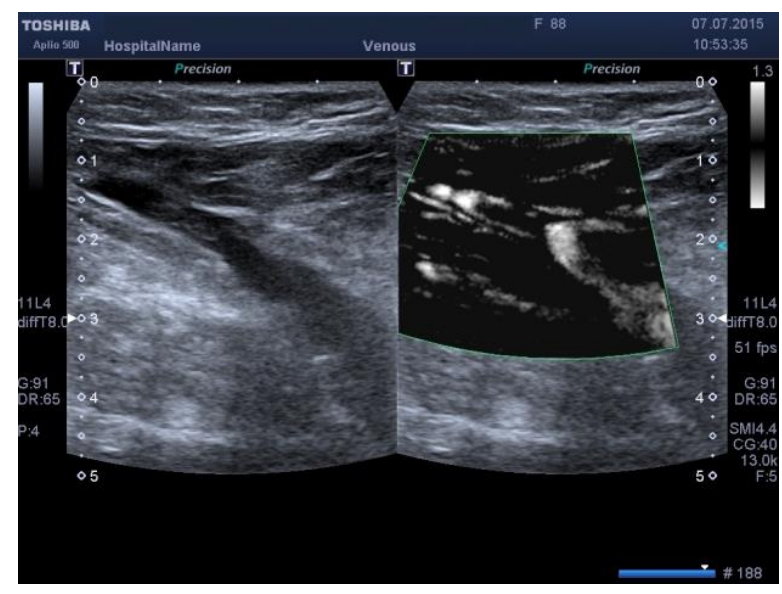

Pис. 9, a.

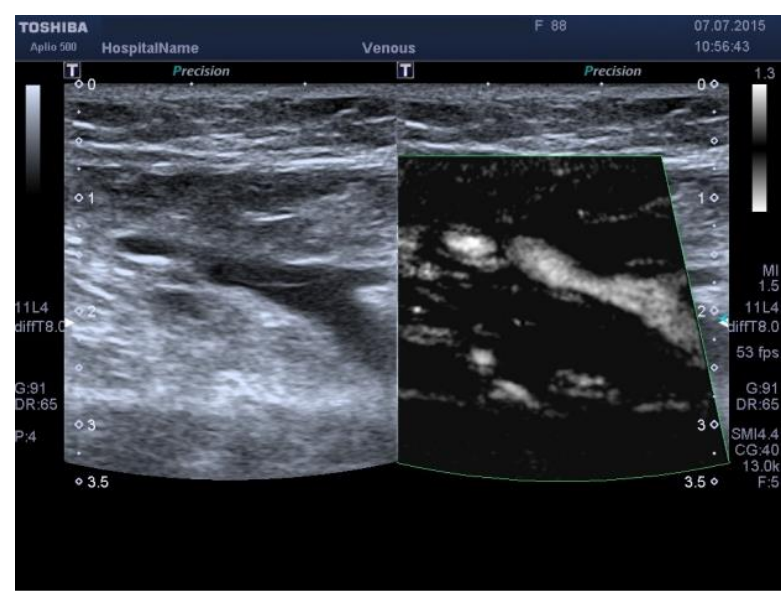

Рис. 9, b.

\section{Рис. 9. Sonograms.}

After one week term visualization of SFA lumen and CFV in B-mode didn't changed significantly. In accordance with data of investigation in SMI mode we confirmed increase of an area and intensity of a bloodflow, typical patterns of active processes of blood clot retraction. Thus, prognosis of thrombotic process is relatively positive and administered thrombolytic therapy is correct. 


\section{RUSSIAN ELECTRONIC JOURNAL OF RADIOLOGY}

information, which helps to work out treatment algorithm based on understanding of pathogenesis and symptoms of the disease.

\section{Conclusion:}

1.Color mapping provided by Acoustic Structures Quantification mode allows precise assessment of thrombotic masses echostructure.

2.Method of tissue elastic properties assessment by color mapping allows detecting nonocclusive thrombosis without compressive probes due to different elastic properties of blood and thrombotic masses.

3.SMI technology, being a highly sensitive tool, makes possible revealing of early signs of thrombotic masses recanalization which cannot be revealed by a standard ultrasound examination.

4.High frame per seconds (50 fps and be-

\section{References:}

1. Shevtchenko Yu.L., Stoyko Yu.M. Fundamental of clinical phlebology. M., "Shiko", 2013. 336 p.

2. Toshiba Medical System. Superb Micro-Vascular Imaging (SMI). http: //medical. Toshiba. com/products/ul/general/aplio500/clinical-applications.

3. Cui, X Wetal., World Journal of Gastroenterology, 2013.

4. Wu L., Yen H.-H., Soon M.-S. Spoke-wheel sign of focal nodular hyperplasia revealed by superb micro-vascular ultrasound imaging. Available at: yond) and ability to detect bloodflow with dramatically low speed scale (up to $1.3 \mathrm{~cm} / \mathrm{sec}$ ) are distinctive characteristics of SMI mode.

5.Accuracy of SMI when used for low speed scale bloodflow evaluation is compared with contrast enhanced ultrasonography (CEUS).

6.Opportunity to use SMI many times during follow-up allows evaluating and tracking the level of recanalization process activity, assessing efficacy of administered therapy.

7.Minimal motion artifacts we registered in some patients did not hinder visualization as in conventional color and power doppler modes which can be explained by high resolution of this technology.

8.Results of our study suggest rationality of ASQ, USE and SMI implementation in patients with venous thrombosis.

http://m.qimed.oxfordjournals.org/content/ 108/8/669.full 5. Simply Superb Microvascular Imaging, published by European Hospital. Available at: http://www.healthcare-ineurope.com/en/article/13047-simply-superb-microvascularimaging.html

6. Ma Yan, Li Gang, Li Jing, Ren Wei-dong. The Diagnostic Value of Superb Microvascular Imaging (SMI) in Detecting Blood Flow Signals of Breast Lesions. A Preliminary Study Comparing SMI to Color Doppler Flow Imaging. 2015; 94 (36). 